\title{
Medical Practitioners' Knowledge about and Attitude towards Transgenders in India
}

\author{
Article by Pethuru Devadason ${ }^{1}$, Sreedhar Muthyala ${ }^{2}$, Liaquat Roopesh Johnson ${ }^{3}$, Alber M. \\ Mathiyarasu ${ }^{4}$, Diana Thamby Ebenezer ${ }^{5}$ \\ ${ }^{I}$ Professor, Department of Community Medicine, Sree Mookambika Institute of Medical \\ Sciences, India \\ ${ }^{2}$ Professor, Department of Community Medicine, Osmania Medical College, Hyderabad, India \\ ${ }^{3}$ Associate Professor, Department of Community Medicine, Azeezia Institute of Medical Sciences \\ and Research, India \\ ${ }^{4}$ Assistant Professor, Department of Community Medicine, Govt. Medical College, Asaripallam, \\ India \\ ${ }^{5}$ Registrar in Paediatrics, Shifa Al Jazeera Medical Centre, Kuwait \\ E-mail:drpethuru@rediffmail.com ${ }^{1}$,sreedhar2612@yahoo.co.in²,liaquat99@gmail.com³, \\ majellaalber@gmail.com ${ }^{4}$,drdiana@rediffmail.com ${ }^{5}$
}

\begin{abstract}
Transgender is an umbrella term that refers to people with diverse gender identities and expressions that differ from stereotypical gender norms. Medical practitioners' attitude towards Transgenders affects health care offered to such patients who experience health and health care disparities and have specific health care needs. There is sparse of literature that explores the knowledge and attitudes of health care providers towards Transgenders.

Objectives: This study was carried out with the following two objectives: 1) to assess the Indian Medical Practitioners' knowledge about and attitude towards Transgenders. 2) To find out the current exposure and self-efficiency of Medical practitioners on treating transgender persons in their clinical set up and to identify the significant factors associated with them.

Methodology: This is a web based cross sectional study carried out among the Medical Practitioners of Allopathic medical system, all over India to assess their knowledge about and attitude towards Transgenders through an online survey questionnaire. The questionnaire collected the basic socio demographic details and clinical practice details of the participants. It also contained set of questions to assess their knowledge, attitude, current exposure of treating transgender individuals and their comfort level (self-efficiency) on treating them.

Results: There were 128 Medical practitioners who completed the online survey questionnaire within one month duration of the study period. Two third of the respondents are residing in urban area (81 $63.3 \%)$ and two third of them (68 - 67.2\%) are working in tertiary care centre setups. Only 27 (21.1\%) respondents know any transgender personally and only 22 (17.2\%) respondents have treated any transgender so far. The average number of transgender individuals treated by these 22 respondents in the past year and past 1 month is only 4.18 and 0.91 respectively. While 95 (74.5\%) participants correctly responded that the transgenderism due to biological causes, 64 (50.0\%) participants correctly responded that the transgenderism is due to psychosocial causes. Years of experience is the only statistically significant factor affecting the participants' general knowledge on transgenders and having provided treatment to any transgender individual.

Conclusion: 1) The study participants have very good positive attitudes towards transgender individuals while there is a gap in their knowledge on Transgenders. 2) Only 21.1\% respondents know any transgender individual personally and only $17.2 \%$ respondents have treated any transgender individuals. 3) Years of experience is the statistically significant factor associated with having general knowledge on Transgenders and having provided treatment to any transgender individual. 4) The
\end{abstract}


DOI: $10.21522 / \mathrm{TIJPH} .2013 .05 .04 . A r t 013$

ISSN: $2520-3134$

confidence on clinical skills and comfort level of treating the transgender individual are less in the study population and which can be improved by continuing medical educations.

Keywords: Transgenders, Knowledge and Attitude, Medical Practitioners, India, KAP on Transgenders.

\section{Introduction}

Transgender is an umbrella term used to describe people with a wide range of gender identities, which are different from the sex assigned at birth. There are culturally specific terms been used to describe the people who have non-gender binary identities, such as hijra (India), waria (Indonesia), muxé (Mexico), fa'afafine (Samoa), kathoey (Thailand) and Two-Spirit (indigenous North Americans). But nowadays the term 'Transgender' is increasing in familiarity throughout the world ${ }^{1}$. There is no single explanation for why some people are transgender. The transgender expression and experiences are varying with individuals which do not support any simple or unitary explanation as the cause for transgender. Many experts believe that biological factors such as genetic influences and prenatal hormone levels, early experiences, and experiences later in adolescence or adulthood may all these contribute together to the development of transgender identities.

The Constitution of the World Health Organization (WHO) states that the "enjoyment of the highest attainable standard of health is one of the fundamental rights of every human being without distinction of race, religion, political belief, economic or social condition"2. Although medical ethics require health services to be inclusive of all people, some populations have more difficulties than others in reaching this standard of health. Those populations can be defined by age, gender, race or ethnicity, geography, wealth, disability, and also by sexual orientation and gender identity.

Transgender people face discrimination in nearly every aspect of their lives. Anti-discrimination laws in most countries do not protect transgender people from discrimination based on gender identity or gender expression. Transgender people experience high levels of discrimination in employment, housing, health care, education, legal systems, and even in their families. Discrimination affects the access to healthcare for transgender people negatively. In recent years, India has witnessed a growing activism of various NGOs and civil society institutions toward mainstreaming sexually minority groups. Such efforts toward mainstreaming consist of advocating the rights of lesbian, gay, bisexual and transgender groups (LGBTs), campaigning against laws that discriminate their rights, seeking public petition for withdrawal of such laws, and efforts to normalize the recognition and acceptance of LGBT identity categories in India ${ }^{3}$.

Transgender people do have the same health needs as any general population, but may have specific and specialist health-care needs, such as gender-affirming hormone therapy and surgery ${ }^{1}$. It has been widely noted that existing healthcare systems do not always function effectively for the transgender population. There are significant disparities in access to and receipt of healthcare among transgender and gender nonconforming populations. Limited availability of appropriate and competent care and differential access to inclusive health insurance perpetuate these disparities and lead to significant morbidity and mortality ${ }^{4}$. Although much research has focused on the transition related care needs of transgender people, access to primary care is critical and is understudied.

In order to provide universal access to health-care, more knowledge is needed on the barriers that transgender face in accessing health services, including the attitudes of health-care providers, who are ethically bound to provide good quality services, regardless of the personal history or characteristics of the patient. However, provision of appropriate health care services for transgender persons requires cultural competency and skill on the part of the health care provider, and providers need specific skills to address the needs of this population ${ }^{5}$.

Transgender individuals have unique health care needs and experience health disparities. Over the past few decades clinicians have become increasingly aware that transgender individuals may have unique health needs but they are uncertain as to what they are or how to begin to address their issues ${ }^{6}$. (Mayer 
2008). Although the reasons are multifactorial, research suggests that attitudes of healthcare providers (HCPs) may be a contributing factor in both accessing and receiving care ${ }^{7}$

Medical practitioners' attitude towards Transgenders affects health care offered to such patients who experience health and health care disparities and have specific health care needs. There is sparse of literature that explores the knowledge and attitudes of health care providers towards Transgenders. No studies are available in literature on the Indian Medical Practitioners' Knowledge, Attitude and Practice on Transgenders. This justifies the need for this study.

\section{Objectives}

This study was carried out with the following two objectives:

1) To assess the Indian Medical Practitioners' knowledge about and attitude towards Transgenders.

2) To find out the current exposure and self-efficiency of Medical practitioners on treating transgender persons in their clinical set up and to identify the significant factors associated with them.

\section{Materials and methods}

Study Design: This is a web based cross sectional study.

Study Area and Population: This study was carried out among the Medical Practitioners of Allopathic medical system, all over India to assess their knowledge about and attitude towards Transgenders.

Study Period: This study was carried out in the month of June 2017. A peer reviewed, pilot tested questionnaire was used in this study. The link of the online survey questionnaire in Google Form was sent to the forums of Medical Practitioners throughout India through Facebook groups of various national level medical bodies. The questionnaire link was also sent to the set of Emails IDs available with the researcher at national level. Reminders to fill up the survey were sent in the Facebook forums and in Emails once in 10 days for two times and the Data collection process was continued for totally 30 days duration.

The questionnaire collected the basic socio demographic details and clinical practice details of the participants. It also contained set of questions to assess their knowledge, attitude, current exposure of treating transgender individuals and their comfort level (self- efficiency) on treating them. Data collected in Google Form was downloaded in Excel spreadsheet and the Analysis was done using SPSS version 20.

\section{Results}

There were 128 medical practitioners who completed the online survey questionnaire. As given in Table -1 , among them $69(53.9 \%)$ are males and $59(46.1 \%)$ are females. $29(22.7 \%)$ are in the 11-30 years age group; $70(54.7 \%)$ are in the 31-40 years age group; $22(17.2 \%)$ are in the 41-50 years age group and another $7(5.5 .0 \%)$ are in the 51 and above years age group. The range of the age is from 22 to 78 with mean age of 35.73 years with SD 8.21 years.

Two third of the respondents are residing in urban area - $81(63.3 \%)$; while $27(21.1 \%)$ are residing in semi urban and another $20(15.6 \%)$ are in rural area. $110(85.9 \%)$ respondents are married and $18(14.1 \%)$ are single. Regarding religion, $90(70.3 \%)$ are Hindus; 22 (17.2\%) are Christians; 14 (10.9\%) are Muslims and another $2(1.6 \%)$ are Atheists.

The respondents are geographically widely spread all over India which is evident for their wide linguistic variability (Figure - 1). People who speak 12 different languages as their mother tongue have participated in the survey. While one third 48 (37.5\%) speak Tamil as mother tongue, 24 (18.8\%) speak Hindi; 10 (7.8\%) each speak Malayalam and Telugu. Other languages are Bengali (9 -7.0\%), Marathi (8 $6.3 \%)$, Gujarathi $(5-3.9 \%)$, Urdu $(4-3.1 \%)$ and Tulu, Odia and Kashmiri are $2(1.6 \%)$ each.

Of the 128 medical Practitioners, two third 86 (65.6\%) do have MD/MS Degree; 28 (21.9\%) have MBBS Degree. Another 9 (7.0\%) have PG Diploma / Fellowship certificates after MBBS Degree and 7 (5.5\%) have Super specialty $(\mathrm{DM} / \mathrm{MCh} / \mathrm{PhD})$ Degree. Two third of them $68(67.2 \%)$ are working in tertiary care centre setups while $21(16.4 \%)$ are working in secondary care setup and another $21(16.4 \%)$ are working in primary care setup. 
DOI: $10.21522 / \mathrm{TIJPH} .2013 .05 .04 . A r t 013$

ISSN: $2520-3134$

The experience of the respondents ranges from fresh graduates to 50 years with mean of 10.61 years with SD of 7.91 years. Only $27(21.1 \%)$ respondents know any transgender personally and only 22 (17.2\%) respondents have treated any transgender so far. The number of Transgenders treated by these 22 respondents in the past 1 year ranges from minimum 1 to maximum 24 transgender individuals with mean of 4.18 and SD of 5.15. The same number in the last months ranges from 0 to maximum 5 with mean of 0.91 with SD of 1.51 .

Table 1. Socio demographic characteristics of the respondents

\begin{tabular}{|c|c|c|c|}
\hline Factors & Category & Frequency & Percentage \\
\hline \multirow{2}{*}{ Gender } & Male & 69 & 53.9 \\
\hline & Female & 59 & 46.1 \\
\hline \multirow{4}{*}{ Age } & 1. 21-30 Yrs & 29 & 22.7 \\
\hline & 2. 31-40 Yrs & 70 & 54.7 \\
\hline & 3. $41-50 \mathrm{Yrs}$ & 22 & 17.2 \\
\hline & 4. $>51 \mathrm{Yrs}$ & 7 & 5.5 \\
\hline \multirow{3}{*}{ Area of Residence } & Urban & 81 & 63.3 \\
\hline & Semi Urban & 27 & 21.1 \\
\hline & Rural & 20 & 15.6 \\
\hline \multirow{2}{*}{ Marital Status } & Married & 110 & 85.9 \\
\hline & Single & 18 & 14.1 \\
\hline \multirow{4}{*}{ Religion } & Hindu & 90 & 70.3 \\
\hline & Christian & 22 & 17.2 \\
\hline & Muslim & 14 & 10.9 \\
\hline & Atheist & 2 & 1.6 \\
\hline \multirow{4}{*}{ Degree } & MBBS & 28 & 21.9 \\
\hline & PG Diploma / Fellowship & 9 & 7.0 \\
\hline & $\mathrm{MD} / \mathrm{MS}$ & 84 & 65.6 \\
\hline & $\mathrm{DM} / \mathrm{MCh} / \mathrm{PhD}$ & 7 & 5.5 \\
\hline \multirow{3}{*}{ Area of Practice } & Primary Health Care & 21 & 16.4 \\
\hline & Secondary Health Care & 21 & 16.4 \\
\hline & Tertiary Health Care & 86 & 67.2 \\
\hline
\end{tabular}




\section{Distribution of Participants by Mother Tongue}

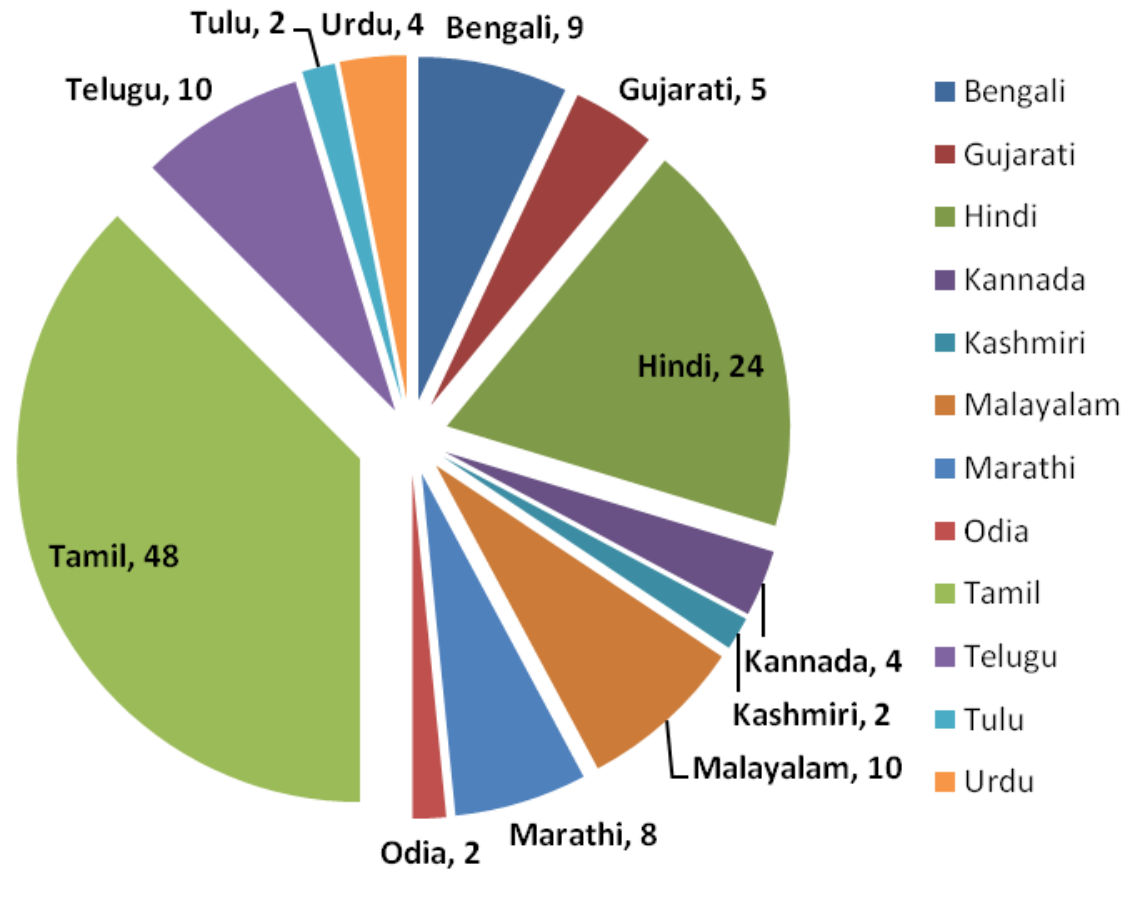

Figure 1. Distribution of participants by mother tongue

Regarding having the general knowledge on the transgenders, $24(18.8 \%)$ said they have adequate knowledge and $76(59.4 \%)$ said they have some knowledge. 26 (20.3\%) said they know very little and 2 (1.6\%) said they know nothing at all. $95(74.5 \%)$ participants correctly responded that the transgenderism due to biological causes; 27 (21.1\%) responded wrongly that the transgenderism is not due to biological causes and $6(4.7 \%)$ responded as 'Don't know'. In the same manner, 64 (50.0\%) participants correctly responded that the transgenderism is due to psychosocial causes; $56(43.8 \%)$ responded wrongly that the transgenderism is not due to biological causes and $8(6.3 \%)$ responded as 'Don't know'.

Table 2. Knowledge on transgenders

\begin{tabular}{|l|l|l|l|}
\hline KNOWLEDGE & Category & Frequency & Percentage \\
\hline \multirow{3}{*}{$\begin{array}{l}\text { Having General } \\
\text { Knowledge on } \\
\text { Transgenders }\end{array}$} & $\begin{array}{l}\text { I have adequate } \\
\text { knowledge }\end{array}$ & 24 & 18.8 \\
\cline { 2 - 4 } & I have some knowledge & 76 & 59.4 \\
\cline { 2 - 4 } & I know very little & 26 & 20.3 \\
\cline { 2 - 4 } & I know nothing at all & 2 & 1.6 \\
\hline \multirow{2}{*}{$\begin{array}{l}\text { Knowing any Trangender } \\
\text { Personally }\end{array}$} & Yes & 27 & 21.1 \\
\cline { 2 - 4 } & No & 98 & 76.6 \\
\cline { 2 - 4 } & Not Sure & 3 & 2.3 \\
\hline \multirow{2}{*}{$\begin{array}{l}\text { Have Provided Services } \\
\text { to Trangenders }\end{array}$} & Yes & 22 & 17.2 \\
\cline { 2 - 4 } & No & 97 & 75.8 \\
\cline { 2 - 4 } & Not Sure & 95 & 74.2 \\
\hline Trangenderism is due to & Yes & 95 & \\
\hline
\end{tabular}


DOI: $10.21522 / \mathrm{TIJPH} .2013 .05 .04 . A r t 013$

ISSN: $2520-3134$

\begin{tabular}{|l|l|l|l|}
\hline Biological Causes & No & 27 & 21.1 \\
\cline { 2 - 4 } & Don't know & 6 & 4.7 \\
\hline \multirow{3}{*}{$\begin{array}{l}\text { Trangenderism is due to } \\
\text { Psychosocial Causes }\end{array}$} & Yes & 64 & 50.0 \\
\cline { 2 - 4 } & No & 56 & 43.8 \\
\cline { 2 - 4 } & Don't know & 8 & 6.3 \\
\hline
\end{tabular}

Table -3 shows the Attitude of the respondents towards the Transgender individuals. It explores their attitudes on transgender individuals about their human values, dignity, struggles, rights and privileges. Overall, the participants have very positive attitude towards Transgender.

Table 3. Attitude towards transgender

\begin{tabular}{|c|c|c|c|c|c|}
\hline ATTITUDE & $\begin{array}{l}\text { Strongly } \\
\text { Agree }\end{array}$ & $\begin{array}{l}\text { Somewhat } \\
\text { Agree }\end{array}$ & $\begin{array}{l}\text { Neither } \\
\text { Agree nor } \\
\text { Disagree }\end{array}$ & $\begin{array}{l}\text { Somewhat } \\
\text { Disagree }\end{array}$ & $\begin{array}{l}\text { Strongly } \\
\text { Disagree }\end{array}$ \\
\hline $\begin{array}{l}\text { 1) Transgender individuals are } \\
\text { valuable human beings } \\
\text { regardless of how I feel about } \\
\text { transgenderism. }\end{array}$ & $\begin{array}{l}112 \\
(87.5 \%)\end{array}$ & $10(7.8 \%)$ & $6(4.7 \%)$ & 0 & 0 \\
\hline $\begin{array}{l}\text { 2) Transgender individuals are } \\
\text { human beings with their own } \\
\text { struggles, just like the rest of } \\
\text { us. }\end{array}$ & $\begin{array}{l}113 \\
(88.3 \%)\end{array}$ & $\begin{array}{l}14 \\
(10.9 \%)\end{array}$ & 0 & $1(0.8 \%)$ & 0 \\
\hline $\begin{array}{l}\text { 3) Transgender individuals } \\
\text { NEED NOT be treated with } \\
\text { the same respect and dignity as } \\
\text { any other person. }\end{array}$ & $7(5.5 \%)$ & $3(2.3 \%)$ & $1(0.8 \%)$ & $9(7.0 \%)$ & $\begin{array}{l}108 \\
(84.4 \%)\end{array}$ \\
\hline $\begin{array}{l}\text { 4) Transgender individuals } \\
\text { should have the same access to } \\
\text { health care facilities as any } \\
\text { other person. }\end{array}$ & $\begin{array}{l}123 \\
(96.1 \%)\end{array}$ & $2(1.6 \%)$ & $1(0.8 \%)$ & $1(0.8 \%)$ & $1(0.8 \%)$ \\
\hline $\begin{array}{l}\text { 5) Transgender individuals } \\
\text { NEED NOT be given } \\
\text { provision for quota in } \\
\text { education and jobs }\end{array}$ & $13(10.2 \%)$ & $11(8.6 \%)$ & $23(18 \%)$ & $27(21.1 \%)$ & $54(42.2 \%)$ \\
\hline
\end{tabular}

Table 4 shows some more opinions of the participants about their medical training and clinical experience.

Table 4. Opinion on medical training and clinical experiences related to transgenders

\begin{tabular}{|l|l|l|l|l|l|}
\hline Opinion & $\begin{array}{l}\text { Strongly } \\
\text { Agree }\end{array}$ & $\begin{array}{l}\text { Somewhat } \\
\text { Agree }\end{array}$ & Not Sure & $\begin{array}{l}\text { Somewhat } \\
\text { Disagree }\end{array}$ & $\begin{array}{l}\text { Strongly } \\
\text { Disagree }\end{array}$ \\
\hline $\begin{array}{l}\text { 1) Your medical education } \\
\text { and training has prepared you } \\
\text { to provide care for } \\
\text { transgender patients? }\end{array}$ & $22(17.2 \%)$ & $33(25.8 \%)$ & $39(30.5 \%)$ & $19(14.8 \%)$ & $15(11.7 \%)$ \\
\hline $\begin{array}{l}\text { 2) You have adequate clinical } \\
\text { ability to provide clinical } \\
\text { services to Transgender in } \\
\text { your health care facility? }\end{array}$ & $27(21.1 \%)$ & $52(40.6 \%)$ & $30(23.4 \%)$ & $8(6.3 \%)$ & $11(8.6 \%)$ \\
\hline
\end{tabular}




\begin{tabular}{|l|l|l|l|l|l|}
\hline $\begin{array}{l}\text { 3) Your are competent in } \\
\text { dealing with a transgender } \\
\text { patient's sexual health } \\
\text { concerns? }\end{array}$ & $13(10.2 \%)$ & $42(32.8 \%)$ & $34(26.6 \%)$ & $18(14.1 \%)$ & $21(16.4 \%)$ \\
\hline $\begin{array}{l}\text { 4) As compared to the general } \\
\text { public, people at health care } \\
\text { facilities have better } \\
\text { understanding and acceptance } \\
\text { on Transgenders. }\end{array}$ & $24(18.8 \%)$ & $60(46.9 \%)$ & $16(12.5)$ & $20(15.6 \%)$ & $8(6.3 \%)$ \\
\hline $\begin{array}{l}\text { 5) Transgender individuals } \\
\text { can be trained and utilized in } \\
\text { the health care team as like } \\
\text { the rest of us. }\end{array}$ & $82(64.1 \%)$ & $38(29.7 \%)$ & $3(2.3 \%)$ & $2(1.6 \%)$ & $3(2.3 \%)$ \\
\hline
\end{tabular}

Table -5 shows the comfort level (self-efficiency) of the participants on treating transgender individuals in general and specific to their sexual health issues.

Table 5. Self - Efficiency on treating transgenders

\begin{tabular}{|l|l|l|l|l|}
\hline SELF EFFICEINCY & Comfortable & Not Sure & $\begin{array}{l}\text { Un- } \\
\text { comfortable }\end{array}$ & $\begin{array}{l}\text { Not } \\
\text { Applicable }\end{array}$ \\
\hline $\begin{array}{l}\text { 1) Your personal comfort level in being } \\
\text { known as a healthcare provider to people } \\
\text { including transgender patients? }\end{array}$ & $66(51.6 \%)$ & $17(13.3 \%)$ & $4(3.1 \%)$ & $41(32.0 \%)$ \\
\hline $\begin{array}{l}\text { 2) Your professional comfort level in } \\
\text { providing care to a transgender patient in } \\
\text { a clinical setting along with other } \\
\text { patients? }\end{array}$ & $66(51.6 \%)$ & $22(17.2 \%)$ & $3(2.3 \%)$ & $37(28.9 \%)$ \\
\hline $\begin{array}{l}\text { 3) Your personal comfort level with } \\
\text { providing prostate exams for male to } \\
\text { female (MTF) transgender patients? }\end{array}$ & $25(19.5 \%)$ & $38(29.7 \%)$ & $8(6.3 \%)$ & $57(44.5 \%)$ \\
\hline $\begin{array}{l}\text { 4) Your personal comfort level with } \\
\text { providing vaginal examination to female } \\
\text { to male (FTM) transgender patients? }\end{array}$ & $32(25.0 \%)$ & $35(27.3 \%)$ & $10(7.8 \%)$ & $51(39.8 \%)$ \\
\hline $\begin{array}{l}\text { 5) Your personal comfort level with been } \\
\text { identified along with transgender in social } \\
\text { gatherings. }\end{array}$ & $48(37.5 \%)$ & $30(23.4)$ & $11(8.6 \%)$ & $39(30.5 \%)$ \\
\hline
\end{tabular}

Table 6. Socio demographic factors and general knowledge on transgenders

\begin{tabular}{|c|c|c|c|c|c|c|}
\hline \multirow{2}{*}{\multicolumn{2}{|c|}{ Factors }} & \multicolumn{2}{|c|}{ General Knowledge } & \multirow{2}{*}{$\begin{array}{l}\text { Chi }^{2} \\
\text { Value }\end{array}$} & \multirow{2}{*}{ DF } & \multirow{2}{*}{$\begin{array}{l}p \text { - } \\
\text { Value }\end{array}$} \\
\hline & & \multirow{2}{*}{$\begin{array}{l}\text { Yes }(\mathbf{N}=100) \\
44(44.0 \%)\end{array}$} & \multirow{2}{*}{$\begin{array}{l}\text { No }(\mathbf{N}=\mathbf{2 8}) \\
9(32.1 \%)\end{array}$} & & & \\
\hline \multirow{2}{*}{ Age } & Higher (53) & & & \multirow{2}{*}{1.268} & \multirow{2}{*}{1} & \multirow{2}{*}{0.260} \\
\hline & Lower (75) & $56(56.0 \%)$ & $19(67.9 \%)$ & & & \\
\hline \multirow[b]{2}{*}{ Gender } & Male (69) & $55(55.0 \%)$ & $14(50.0 \%)$ & \multirow[b]{2}{*}{0.220} & \multirow[b]{2}{*}{1} & \multirow[b]{2}{*}{0.639} \\
\hline & $\begin{array}{l}\text { Female } \\
(59)\end{array}$ & $45(45.0 \%)$ & $14(50.0 \%)$ & & & \\
\hline \multirow{2}{*}{ Area of Residence } & Urban $(81)$ & $64(64.0 \%)$ & $17(60.7 \%)$ & \multirow{2}{*}{0.102} & \multirow{2}{*}{1} & \multirow{2}{*}{0.750} \\
\hline & Others (47) & $36(36.0 \%)$ & $11(39.3 \%)$ & & & \\
\hline Degree & Higher (91) & $76(76.0 \%)$ & $15(53.6 \%)$ & 9.581 & 1 & $0.002 *$ \\
\hline
\end{tabular}


DOI: $10.21522 /$ TIJPH.2013.05.04.Art013

ISSN: $2520-3134$

\begin{tabular}{|c|c|c|c|c|c|c|}
\hline & Lower (37) & $24(24.0 \%)$ & $13(46.4 \%)$ & & & \\
\hline \multirow{2}{*}{ Experience } & Higher (62) & $54(54.0 \%)$ & $8(28.6 \%)$ & \multirow{2}{*}{5.663} & \multirow{2}{*}{1} & \multirow{2}{*}{$0.017 \propto$} \\
\hline & Lower (66) & $46(46.0 \%)$ & $20(71.4 \%)$ & & & \\
\hline \multirow{2}{*}{ Area of Practice } & $\begin{array}{l}\text { Tertiary } \\
(86)\end{array}$ & $68(68.0 \%)$ & $18(64.3 \%)$ & \multirow[t]{2}{*}{0.137} & \multirow[t]{2}{*}{1} & \multirow{2}{*}{0.711} \\
\hline & Others (42) & $32(32.0 \%)$ & $10(35.7 \%)$ & & & \\
\hline \multirow{2}{*}{$\begin{array}{l}\text { Knowing } \\
\text { Transgender } \\
\text { Personally }\end{array}$} & Yes (27) & $27(27.0 \%)$ & $0(0.0 \%)$ & \multirow[b]{2}{*}{9.581} & \multirow[b]{2}{*}{1} & \multirow[b]{2}{*}{$0.002 *$} \\
\hline & No (101) & $73(73.0 \%)$ & $28(100 \%)$ & & & \\
\hline
\end{tabular}

*Statistically significant at $1 \% ; \infty$ statistically significant at $5 \%$.

The above table shows the factors like higher level of Degree, more years of Experience and Knowing the Transgender individual personally are significantly more associated with having a good knowledge about Transgenders, as denoted by the significant $\mathrm{p}$ - values.

In the Logistic Regression Analysis, only the factor only the factor Experience is significant.

Table 7. Socio demographic factors and treatment provided to transgender

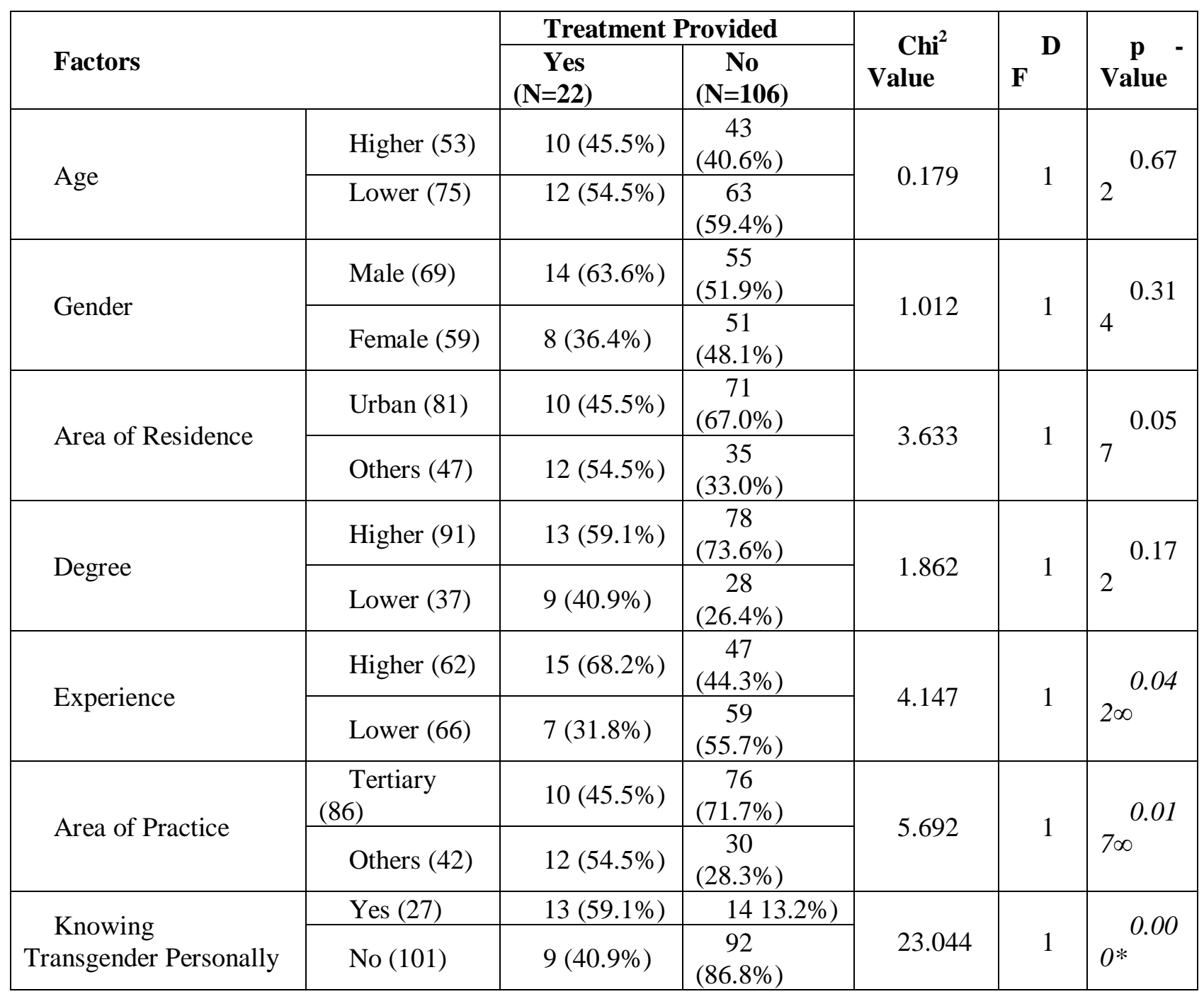

*Statistically significant at $1 \% ; \infty$ statistically significant at $5 \%$. 
The above table shows the factors like more years of Experience, Area of practice and knowing the Transgender individual personally are significantly more associated with having provided treatment to Transgenders, as denoted by the significant $\mathrm{p}$ - values.

In the Logistic Regression Analysis, the factors Experience and Knowing Transgender Personally are significant.

\section{Discussion}

This web based survey was conducted among the Medical Practitioners of Allopathic medical system throughout India. There were 128 medical practitioners who completed the online survey questionnaire within one month duration of the study period. Though the response is low and response rate can't be calculated as there is no measurement of the defined population, the survey covers the whole geographic area of the country as indicated by the various mother tongues of the participants.

India is having two third of its population as Rural, but in this study, two third of the respondents are residing in urban area $(81-63.3 \%)$ and two third of them $(68-67.2 \%)$ are working in tertiary care centre setups. This may be due to inherent characteristics of any online survey as urban population has more internet access and usage in day to day life. Only $27(21.1 \%)$ respondents know any transgender personally and only $22(17.2 \%)$ respondents have treated any transgender so far. The average number of transgender individuals treated by these 22 respondents in the past year and past 1 month is only 4.18 and 0.91 respectively. This shows the poor exposure and experience of the Medical Practioner with Transgender individuals in their daily clinical practice.

Regarding having the general knowledge on the transgender, $24(18.8 \%)$ said they have adequate knowledge and $76(59.4 \%)$ said they have some knowledge. While 95 (74.5\%) participants correctly responded that the transgenderism due to biological causes, $64(50.0 \%)$ participants correctly responded that the transgenderism is due to psychosocial causes. Participants with higher medical degrees and higher experience category were able to answer correctly than others.

From Table -3 , it is obviously seen that the study participants have very good positive opinion regarding the transgender individuals. But their confidence on their clinical skills and their comfort level in treating the general health problems of the transgender individuals and their sexual health problems in particular, most of them are not comfortable and confident as seen in Tables 4 and 5. This is consistent with the findings of the study on 'Internal Medicine Resident Attitudes, Prior Education, Comfort, and Knowledge Regarding Delivering Comprehensive Primary Care to Transgender Patients' by Johnston and Sheare ${ }^{8}$. This may be partly due to the lack of theoretical and practical exposure to transgender health issues during their medical training and lack of much exposure in their clinical day to day practice.

Only $42 \%$ participants agreed that their medical education and training had prepared them to provide care for transgender patients (Table -4). A Study done by Sven E.S. et al concludes that the addition of transgender medicine content to a medical school curriculum with a focus on the biologic evidence for a durable gender identity is an effective means of educating students about the etiology of gender identity and the appropriateness of cross-sex hormone therapy as a treatment for transgender patients. It was also suggested that Medical schools should consider increasing transgender health instruction and measure which type of education, including didactic and clinical methods, can best prepare future physicians to care for this marginalized population with specific health needs. This is also supported by another study by Dylan $D$ et $a l^{10}$ which was carried out among the Postgraduates Interns where the lecture significantly increased residents' knowledge and willingness to assist with hormonal therapy for transgender patients.

Regarding the factors affecting the participants general knowledge on Transgenders (Table -6) and having provided treatment to any transgender individual (Table - 7), the years of Experience is the only statistically significant factor. This shows the more years of clinical experience after the basic medical degree, they are slowly exposed to the Transgenders in due course of time. The study on, 'Transgender Health Education Impact on Medical Student Knowledge, Skills and Attitudes' by Dowshen Nadia et al ${ }^{11}$ shows that even with a few hours of instruction on transgender health would bring a significant changes 
DOI: $10.21522 / \mathrm{TIJPH} .2013 .05 .04 . A r t 013$

ISSN: $2520-3134$

in score on knowledge, attitude and skills of the participants. So, appropriate curriculum in the medical training and periodic continuing medical education on transgender health issues will improve the confidence and comfort level of the medical practitioners to treat the transgender individuals along with other regular patients in their daily practice.

\section{Conclusion}

1. The study participants have very good positive attitudes towards transgender individuals while there is a gap in their knowledge on Transgenders.

2. Only $21.1 \%$ respondents know any transgender individual personally and only $17.2 \%$ respondents have treated any transgender individuals.

3. Years of experience is the statistically significant factor associated with having general knowledge on transgenders and having provided treatment to any transgender individual

4. The confidence on clinical skills and comfort level of treating the transgender individual are less in the study population and which can be improved by continuing medical educations.

\section{Significance / Recommendations}

1. The study population has good positive attitudes towards Transgender individuals and less exposure and experience in treating them regularly in their clinical practice and lower level of comfort. This shows, there is a need for and scope to improve their knowledge on transgender health issues.

2. Country like India which is having a vast geographical area and wide variation in the regional socio cultural factors, further studies bigger samples and covering all the regions including the rural area will bring out the reality.

\section{References}

[1]. Dorsen, C. and Van Devanter, N. (2016), open arms, Conflicted hearts: Nurse-practitioner's Attitudes towards working with Lesbian, Gay and Bisexual patients. J Clin Nurs, 25: 3716-3727. doi:10.1111/jocn.13464

[2]. Dylan D. Thomas and Joshua D. Safer (2015). A simple intervention raised Resident - Physician willingness to assist Transgender patients seeking hormone therapy. Endocrine Practice: October 2015, Vol. 21, No. 10, pp. 11341142.

[3]. Edmiston EK, Donald CA, Sattler AR, Peebles JK, Ehrenfeld JM, Eckstrand KL (2016) Opportunities and gaps in primary care preventative health services for transgender patients: a systematic review, Transgender Health 1:1, 216-230, DOI: 10.1089/trgh.2016.0019.

[4]. Johnston, C. D., \& Shearer, L. S. (2017). Internal Medicine Resident Attitudes, Prior Education, Comfort, and Knowledge Regarding Delivering Comprehensive Primary Care to Transgender Patients. Transgender Health, 2(1), 91-95. http://doi.org/10.1089/trgh.2017.0007.

[5]. Mayer HK, Bradford BJ, Makadon JH, Stall R, Goldhammer, H, Landers S. Sexual and gender minority health: What we know and what needs to be done. American Journal of Public Health; 2008; 98(6): 989-995. PMid: 18445789 http://dx.doi.org/10.2105/AJPH.2007.127811.

[6]. Nadia Dowshen, Kea Gilbert, Alana Feiler, Susan Lee, Nadia et al. Transgender Health Education Impact on Medical Student Knowledge, Skills and Attitudes. Journal of Adolescent Health, Volume 52, Issue 2, S35. DOI: http://dx.doi.org/10.1016/j.jadohealth.2012.10.085.

[7]. Preamble to the Constitution of the World Health Organization as adopted by the International Health Conference, New York, 19-22 June, 1946; signed on 22 July 1946 by the representatives of 61 States, entered into force on 7April 1948.

[8]. Rebekah Thomas, Frank Pega, Rajat Khosla, Annette Verster, Tommy Hanaa, Lale Say. Perspective: Ensuring an inclusive global health agenda for transgender people. Bull World Health Organ 2017; 95:154-156 | doi: http://dx.doi.org/10.2471/BLT.16.183913.

[9]. Subir K Kole. Globalizing queer? AIDS, homophobia and the politics of sexual identity in India. Globalization and Health20073:8. https://doi.org/10.1186/1744-8603-3-8. 
Texila International Journal of Public Health Volume 5, Issue 4, Dec 2017

[10]. Selix, N. W. and Rowniak, S. (2016), Provision of Patient-Centered Transgender Careimage. Journal of Midwifery \& Women's Health, 61: 744-751. doi:10.1111/jmwh.12518.

[11]. Sven E.S. Eriksson and Joshua D. Safer (2016). Evidence-based curricular content improves Student Knowledge and changes Attitudes towards Transgender Medicine. Endocrine Practice: July 2016, Vol. 22, No. 7, pp. 837-841. https://doi.org/10.4158/EP151141.OR. 